\title{
Metabolism of 2,4-dichlorophenoxyacetic acid, 4-chloro-2-methylphenoxyacetic acid and 2-methylphenoxyacetic acid by Alcaligenes eutrophus JMP 134
}

\author{
Dietmar Helmut Pieper ${ }^{1}$, Walter Reineke ${ }^{2}$, Karl-Heinrich Engesser ${ }^{1}$, and Hans-Joachim Knackmuss ${ }^{1}$ \\ ${ }^{1}$ Institut für Mikrobiologie der Universität Stuttgart, D-7000 Stuttgart 1, Federal Republic of Germany \\ ${ }^{2}$ Lehrstuhl für chemische Mikrobiologie der Bergischen Universität - Gesamthochschule Wuppertal, D-5600 Wuppertal 1, \\ Federal Republic of Germany
}

\begin{abstract}
Of eleven substituted phenoxyacetic acids tested, only three (2,4-dichloro-, 4-chloro-2-methyl- and 2methylphenoxyacetic acid) served as growth substrates for Alcaligenes eutrophus JMP 134. Whereas only one enzyme seems to be responsible for the initial cleavage of the ether bond, there was evidence for the presence of three different phenol hydroxylases in this strain. 3,5-Dichlorocatechol and 5-chloro-3-methylcatechol, metabolites of the degradation of 2,4-dichlorophenoxyacetic acid and 4-chloro-2-methylphenoxyacetic acid, respectively, were exclusively metabolized via the ortho-cleavage pathway. 2-Methylphenoxyacetic acid-grown cells showed simultaneous induction of meta- and ortho-cleavage enzymes. Two catechol 1,2dioxygenases responsible for ortho-cleavage of the intermediate catechols were partially purified and characterized. One of these enzymes converted 3,5-dichlorocatechol considerably faster than catechol or 3-chlorocatechol. A new enzyme for the cycloisomerisation of muconates was found, which exhibited high activity against the ring-cleavage products of 3,5-dichlorocatechol and 4-chlorocatechol, but low activities against 2-chloromuconate and muconate.
\end{abstract}

Key words: Phenoxyacetic acids - Phenols - Catechols Muconates - Alcaligenes eutrophus JMP 134 - Orthocleavage pathways - Meta-cleavage pathway

The bacterial degradation of 2,4-dichlorophenoxyacetic acid (2,4-D) and 4-chloro-2-methylphenoxyacetic acid (MCPA) has been investigated by various research groups. In general, the metabolism is initiated by cleavage of the ether bond (Loos et al. 1967; Tiedje and Alexander 1969; Evans et al. 1971 b; Gamar and Gaunt 1971) followed by orthohydroxylation of the phenolic product to produce a catechol (Bollag et al. 1968a; Beadle and Smith 1982). Variations of this pathway have been reported. Evans et al. (1971 b) and Gaunt and Evans (1971 a) postulated in addition an aerobic reductive elimination of chloride. An initial hydroxylation of 4-chlorophenoxyacetic acid to give 4-chloro-2hydroxyphenoxyacetic acid was shown by Evans et al.

Offprint requests to: $\mathrm{H}$.-J. Knackmuss

Non-standard abbreviations: MCPA, 4-chloro-2-methylphenoxyacetic acid;2MPA, 2-methylphenoxyacetic acid; PA, phenoxyacetic acid
(1971 a). Also 2,4-D was converted partially to 2,4-dichloro6-hydroxyphenoxyacetic acid by Pseudomonas NCIB 9340 (Evans et al. 1971 b).

Among bacterial species known to degrade 2,4-D, Alcaligenes eutrophus JMP 134 is one of the best characterized organisms concerning genetic aspects. Genes encoding enzymes for the degradation of 2,4-D by JMP 134 have been localized on a plasmid, pJP4 (Don et al. 1985; Streber et al. 1987) and evidence has been given for a pathway which includes 2,4-dichlorophenol and 3,5-dichlorocatechol as intermediates (Don et al. 1985). Further, Liu and Chapman (1984) described the purification of a pJP4-encoded chlorophenol hydroxylase, which formed 3,5dichlorocatechol from 2,4-dichlorophenol. Don and Pemberton (1981) reported that after transfer of pJP4 to different recipient strains, these strains aquired the ability to degrade 2,4-D. Simultaneously, the ability to mineralize MCPA has been transferred in these experiments. In contrast Friedrich et al. (1983) described transconjugants which were able to degrade 2,4-D but not MCPA. Therefore it is still inconclusive whether the same or similar enzymes are involved in the catabolism of the structurally analogous substrates 2,4-D and MCPA.

Streber et al. (1987) assumed a chromosomally encoded meta-cleavage pathway for phenol degradation by strain JMP 134. Remarkably, only ortho-cleavage mechanisms were discussed as key activities for the assimilation of chlorosubstituted catechols in 2,4-D and MCPA-pathways (Tiedje et al. 1969; Gaunt and Evans 1971 a, b; Evans et al. 1971 b; Kilpi et al. 1983; Don et al. 1985). Since 2,3dioxygenation of chlorosubstituted catechols was shown to generate either suicide (Bartels et al. 1984) or dead-end products (Schacht, unpublished data), it would appear that the meta-cleavage pathway for the degradation of chloroaromatics including 2,4-D or MCPA may be unproductive or even counterproductive.

Generally, nonhalogenated methylsubstituted aromatics are degraded via meta-cleavage pathways (Sala Trepat et al. 1972; Murray et al. 1972; Dagley 1978). Only few microorganisms are known to be able to degrade methylcatechols via modified ortho-cleavage pathways (Miller 1981; Powlowski and Dagley 1985; Pieper et al. 1985), among them being strain JMP 134 which is able to degrade 4-methylcatechol via ortho-cleavage (Pieper et al. 1985). Because degradation of methyl- and chlorosubstituted aromatic compounds 
appears to be incompatible in a single bacterial strain (Reineke and Knackmuss 1980; Latorre et al. 1984; Rubio et al. 1986 ), in the present paper special attention is given to the mode of ring-cleavage during growth of Alcaligenes eutrophus JMP 134 on 2,4-D, MCPA and 2-methylphenoxyacetic acid (2MPA).

\section{Materials and methods}

\section{Organisms}

Alcaligenes eutrophus JMP 134 was isolated on the basis of being able to grow with 2,4-dichlorophenoxyacetic acid $(2,4-$ D) as sole source of carbon and energy (Don and Pemberton 1981).

\section{Culture conditions}

For growth in liquid culture, the mineral medium as described by Dorn et al. (1974) contained $5 \mathrm{mM}$ of the respective substrate.

Cells were grown in 100,1000 or $3000 \mathrm{ml}$ fluted Erlenmeyer flasks containing 10,100 or $500 \mathrm{ml}$ of medium, respectively. The flasks were incubated at $30^{\circ} \mathrm{C}$ on a rotary shaker at $150 \mathrm{rpm}$ and growth was monitored photometrically by measuring the turbidity at $546 \mathrm{~nm}$. Solid media were prepared by the addition of $1.5 \%$ (wt/vol) agar No. 1 (Oxoid) to the mineral medium. The concentration of the carbon source in agar plates was $2 \mathrm{mM}$. Stock cultures were maintained on 2,4-D-containing agar plates.

\section{Preparation of cell extracts}

Cells were harvested during late exponential growth phase and suspended in phosphate-acetone buffer $(100 \mathrm{mM}$, $\mathrm{pH}$ 7.5) (Nozaki 1970) for catechol 2,3-dioxygenase (C230) and 2-hydroxy-6-oxohexa-2,4-dienoate hydrolase (2-hydroxymuconic semialdehyde hydrolase, HMSH) and in Trishydrochloride buffer (100 mM, pH 7.5) (Dorn and Knackmuss 1978a) for the other enzymes tested. The cell suspension were disrupted using a French-press (Aminco, Silver Spring, MD, USA) and the cell debris was removed by centrifugation at $100,000 \times g$ for $1 \mathrm{~h}$ at $4^{\circ} \mathrm{C}$. Cell extracts were used the same day.

\section{Enzyme assays}

Catechol 2,3-dioxygenase (C230, EC 1.13.11.2) was assayed by the method of Nozaki (1970). Catechol 1,2-dioxygenase (C120, EC 1.13.11.1) activity was measured by the procedure of Dorn and Knackmuss (1978a, b). Extinction coefficients were those reported by Dorn and Knackmuss (1978b). If C230 was simultaneously induced, this enzyme was inactivated by treating the extract with $\mathrm{H}_{2} \mathrm{O}_{2}(0.01 \%)$ for $10 \mathrm{~min}$ before adding the test substrate (Nakazawa and Yokota 1973). 2-Hydroxymuconic semialdehyde hydrolase (HMSH) was asssayed as described by Williams and Murray (1974). cis,cis-Muconate cycloisomerase (EC 5.5.1.1) was assayed by the method of Schmidt and Knackmuss (1980) using cis, cis-muconate and 2-chloro-cis, cis-muconate as substrates. Further substrates were prepared in situ by incubation of 4-chlorocatechol and 3,5-dichlorocatechol with partially purified catechol 1,2-dioxygenase of the type II, which was free of any cycloisomerase activity. Cell extract was added after total conversion of the respective catechol. 4-Carboxymethylenebut-2-en-4-olide hydrolase was measured by the method of Schmidt and Knackmuss (1980) modified by Schlömann (unpublished data) using histidinehydrochloride buffer. 4-Carboxymethylbut-3-en-4-olide hydrolase was assayed as described by Ornston (1966). For the assay of maleylacetate reductase, the method described by Gaal and Neujahr (1980) was modified by using Tris-hydrochloride buffer and NADH. Specific activities are expressed as micromoles of substrate converted or product formed per minute per gram protein at $25^{\circ} \mathrm{C}$. Protein was determined by the Bradford procedure (Bradford 1976).

\section{Activities with whole cells}

For measuring 2,4-D monooxygenase activity freshly harvested cells were resuspended in $50 \mathrm{mM}$ phosphate buffer $(\mathrm{pH} 7.5)$ to an optical density of about 5 and incubated with the respective substrate $(2 \mathrm{mM})$ on a watherbath shaker at $30^{\circ} \mathrm{C}$. Substrate concentrations during incubation were measured by high pressure liquid chromatography (HPLC).

For assaying phenol hydroxylase, the rate of oxygen uptake was measured polarographically by use of a Clarktype oxygen electrode. Freshly harvested cells were washed and resuspended in $50 \mathrm{mM}$ phosphate buffer ( $\mathrm{pH} 7.5)$ to an optical density of about 30 . Of this suspension, $100 \mu$ l were added to $2.8 \mathrm{ml}$ phosphate buffer $(50 \mathrm{mM}, \mathrm{pH} 7.5)$ saturated with air. After 5 min of constant endogenous oxygen uptake, the reaction was started by adding the assay substrate to a final concentration of $0.1 \mathrm{mM}$. Uptake rates were determined at $25^{\circ} \mathrm{C}$ with initial time course rates and corrected for endogenous $\mathrm{O}_{2}$ uptake. Activities are expressed as micromoles of $\mathrm{O}_{2}$ uptake per minute per gram protein. This rate is a total activity of phenol hydroxylases and catechol dioxygenases. Because no accumulation of catechols was found, the activity of phenol hydroxylases must be rate limiting. To make the measured activities comparable with other enzyme activities, they were therefore divided by two. The protein concentration of whole cells was determined according to Schmidt et al. (1963).

\section{Analysis of kinetic data}

The initial-velocities data were examined graphically in double reciprocal plots. Michaelis constants $\left(K_{\mathrm{m}}\right)$ were calculated by the method of Lineweaver and Burk (1934).

\section{DEAE cellulose chromatography}

Cell extract was applied to the top of a DEAE cellulose column $(\varnothing 1.5 \mathrm{~cm} \times 30 \mathrm{~cm})$ which was equilibrated with Tris-hydrochloride buffer $(20 \mathrm{mM}, \mathrm{pH} 8.0$, containing $0.1 \mathrm{mM} \mathrm{NaCl}$ ). The column was washed with the same buffer at a flow rate of about $20 \mathrm{ml} / \mathrm{h}$. A linear gradient $0.1-$ $0.35 \mathrm{M} \mathrm{NaCl}$ in Tris-hydrochloride buffer was applied and $3.5 \mathrm{ml}$ fractions were collected.

\section{Analytical methods}

The concentrations of substituted phenoxyacetic acids and phenols were determined by high pressure liquid chromatography with M-660 solvent programmer and WISP 710 autosampler (Waters Association Inc., Milford, MA, USA) at $210 \mathrm{~nm}$ (detector SF 770, Schoeffel) with column SC 125/ 
Table 1. Relative rates of conversion of various substituted phenoxyacetic acids by freshly harvested cells of Alcaligenes eutrophus JMP 134

\begin{tabular}{llll}
\hline Assay substrate & \multicolumn{2}{l}{ Relative rates " of conversion after growth with } \\
\cline { 2 - 4 } & $\begin{array}{l}\text { 2,4-Dichloro- } \\
\text { phenoxyacetic acid }\end{array}$ & $\begin{array}{l}\text { 4-Chloro-2-methyl- } \\
\text { phenoxyacetic acid }\end{array}$ & $\begin{array}{l}\text { 2-Methyl- } \\
\text { phenoxyacetic acid }\end{array}$ \\
\hline 2,4-Dichlorophenoxyacetic acid & $100(105)$ & $100(21)$ & $100(40)$ \\
4-Chloro-2-methylphenoxyacetic acid & 45 & 45 & 50 \\
2-Methylphenoxyacetic acid & 35 & 45 & 55 \\
Phenoxyacetic acid & 65 & 70 & 70
\end{tabular}

a Cells were harvested during exponential growth. The decrease of substrate concentration was followed by high pressure liquid chromatography. Rates are expressed as percentages of that for 2,4-dichlorophenoxyacetic acid $(=100 \%)$. The specific activities, given in micromoles substrate per minute per gram protein, appear in parentheses

Lichrospher $5 \mu \mathrm{m}$ (Bischoff) in a solvent system containing $1 \mathrm{~g}$ of $\mathrm{H}_{3} \mathrm{PO}_{4}$ and $400-600 \mathrm{ml}$ of methanol per liter of $\mathrm{H}_{2} \mathrm{O}$. Samples of culture fluid $(2-10 \mu \mathrm{l})$ were injected after cells had been removed by centrifugation.

Chloride ion concentration was measured with an ion selective combination electrode (model 96/17, Orion Research Inc., Cambridge, MA, USA) which was calibrated with $\mathrm{NaCl}(0.1-50 \mathrm{mM})$ in mineral medium before each measurement.

\section{Chemicals}

2,4-Dichloro-, 4-chloro-2-methyl- and 4-chlorophenoxyacetic acid, 2-methylphenol, 3-methylcatechol and 4methylcatechol were obtained from Aldrich Chemie, Steinheim, FRG, 2-methyl-, 4-methyl-, 2-chloro- and 2,4dimethylphenoxyacetic acid from Ventron, Karlsruhe, FRG. Phenoxyacetic acid was purchased from Fluka AG, Buchs, Switzerland. 4-Chloro-2-methylphenol and catechol were purchased form Merck AG, Darmstadt, FRG. 3Chloro- and 4-chlorocatechol were prepared as previously described (Schreiber et al. 1980) and 3,5-dichlorocatechol was prepared as described by Dorn and Knackmuss (1978 b). 2-Chloro-4-methylphenoxyacetic acid was prepared from 2 chloro-4-methylphenol by the method of Winnacker and Küchler (1972). 2-Chloro-4-methylphenol was supplied by Bayer AG, Leverkusen, FRG. 5-Chloro-3-methylcatechol was a generous gift from Juha Knuutinen, University of Jyväskylä, Finland. cis,cis-Muconate and 2-chloro-cis,cismuconate were prepared as described by Schmidt et al. (1980), and trans-4-carboxymethylenebut-2-en-4-olide and maleylacetate as described by Reineke and Knackmuss (1984).

\section{Results}

\section{Growth on phenoxyacetic acids}

Strain Alcaligenes eutrophus JMP 134 was tested for growth on solid medium, containing phenoxyacetic acid (PA), 2methyl- (2MPA), 4-methyl-, 2-chloro-, 4-chloro-, 4-chloro2-methyl (MCPA), 2-chloro-4-methyl-, 2,4-dimethyl-, 2,3dichloro-, 2,4-dichloro- (2,4-D) or 3,4-dichlorophenoxyacetic acid. Uniform growth after 5 days of incubation was observed with 2,4-D, MCPA and 2MPA. Also growth in liquid culture was observed with these compounds as sole source of carbon and energy. Substrate concentrations higher than $5 \mathrm{mM}$ inhibited growth on 2,4-D and MCPA.
At substrate concentrations of $5 \mathrm{mM}$ the same growth rate was observed for 2,4-D and 2MPA $\left(\mu=0.17-0.18 \mathrm{~h}^{-1}\right)$ whereas the organism grew considerably slower with MCPA $\left(\mu=0.07 \mathrm{~h}^{-1}\right)$. Corresponding to the amount of substrate consumed, quantitative elimination of chloride was found in cultures growing on 2,4-D or MCPA. The molar growth yield was considerably higher with $2 \mathrm{MPA}(66 \mathrm{~g} / \mathrm{mol})$ than with 2,4-D $(32.4 \mathrm{~g} / \mathrm{mol})$ or MCPA $(31.2 \mathrm{~g} / \mathrm{mol})$.

\section{Initial degradation steps}

No information was available if different enzymes were responsible for the initial attack and further catabolism of differently substituted phenoxyacetic acids by Alcaligenes eutrophus JMP 134. Because the initial enzyme proved to be unstable in cell extracts, experiments were carried out with whole cells. Disappearance of phenoxyacetic acids was monitored by HPLC. The relative rates of conversion of 2,4$\mathrm{D} / \mathrm{MCPA} / 2 \mathrm{MPA} / \mathrm{PA}$ remained constant regardless of which phenoxyacetic acid had been used as growth substrate (Table 1). Therefore a single enzyme (designated as 2,4-D monooxygenase) appears to be responsible for the initial conversion of these compounds.

HPLC analysis revealed that 2,4-D-grown cells accumulated 2-methylphenol when incubated with 2MPA, while 2MPA-grown cells accumulated 2,4-dichlorophenol when incubated with 2,4-D. These metabolites were identified by cochromatography with the authentic compounds.

The different accumulation pattern of the phenols by differently induced cells suggests the presence of different phenolhydroxylases. Comparison of relative $\mathrm{O}_{2}$-consumption rates for different substituted phenols by 2,4-D-, MCPA- and 2MPA-grown cells also showed significant differences (Table 2). 2,4-D- and MCPA-grown cells clearly revealed the highest activity against 2,4-dichlorophenol. Activity was found also against phenol. This activity was about four times higher than that found against 2- and 4methylphenol. 2,4-D-grown cells harvested during early stationary growth phase showed the same activity against 2,4-dichlorophenol as cells harvested during exponential growth phase. These, however, exhibited no activity against phenol, 2- and 4-methylphenol. In contrast, 2MPA-grown cells showed equal activities against phenol and 2- and 4methylphenol, while the activity against 2,4-dichlorophenol was significantly lower.

\section{Cleavage of catechols}

Because strain JMP 134 can synthesize ortho- and metacleavage enzymes, enzyme activities synthesized after growth 
Table 2. Relative rates of oxygen-uptake at the expense of various substituted phenols by freshly harvested and washed cells of Alcaligenes eutrophus JMP 134

\begin{tabular}{|c|c|c|c|}
\hline \multirow[t]{2}{*}{ Assay substrate } & \multicolumn{3}{|c|}{ Relative rates ${ }^{a}$ of conversion after growth with } \\
\hline & $\begin{array}{l}\text { 2,4-Dichloro- } \\
\text { phenoxyacetic acid }\end{array}$ & $\begin{array}{l}\text { 4-Chloro-2-methyl- } \\
\text { phenoxyacetic acid }\end{array}$ & $\begin{array}{l}\text { 2-Methyl- } \\
\text { phenoxyacetic acic }\end{array}$ \\
\hline 2,4-Dichlorophenol & $100^{\circ}(230)$ & $100(130)$ & $100(25)$ \\
\hline 4-Chloro-2-methylphenol & $30^{\circ}$ & $\mathrm{ND}^{\mathrm{c}}$ & 100 \\
\hline 2-Methylphenol & $10^{\mathrm{d}}$ & 15 & 330 \\
\hline 4-Methylphenol & $10^{\mathrm{d}}$ & 15 & 320 \\
\hline Phenol & $40^{d}$ & 65 & 300 \\
\hline
\end{tabular}

a Cells were harvested during exponential growth. The oxygen uptake rates are expressed as percentages of that for 2,4-dichlorophenol (= $100 \%$ ). Specific activities (in parentheses) were estimated on the basis of half of the oxygen uptake rate in micromol $\mathrm{O}_{2}$ per minute per gram protein

ND $=$ not determined

- The same activities were found in cells harvested during early stationary growth phase

${ }^{d}$ No activities were found in cells harvested during early stationary growth phase

Table 3. Specific activities of catabolic enzymes from 2,4-dichlorophenoxyacetic acid (2,4-D)-, 4-chloro-2-methylphenoxyacetic acid (MCPA)- and 2-methylphenoxyacetic acid (2MPA)-grown cells of Alcaligenes eutrophus JMP 134

\begin{tabular}{|c|c|c|c|c|c|}
\hline \multirow[t]{2}{*}{ Enzyme activity } & \multirow[t]{2}{*}{ Assay substrate } & \multicolumn{4}{|c|}{ sp. act. (U/g protein) after growth with ${ }^{a}$} \\
\hline & & 2,4-D & MCPA & 2MPA & Fructose \\
\hline $\begin{array}{l}\text { 2,4-D monooxygenase } \\
\text { Phenol hydroxylase }\end{array}$ & $\begin{array}{l}\text { 2,4-D } \\
\text { 2,4-Dichlorophenol } \\
\text { Phenol } \\
\text { 2-Methylphenol }\end{array}$ & $\begin{array}{r}105 \\
230 \\
130 \\
35\end{array}$ & $\begin{array}{r}21 \\
130 \\
75 \\
20\end{array}$ & $\begin{array}{l}40 \\
25 \\
80 \\
90\end{array}$ & $\begin{array}{r}6 \\
12 \\
<5 \\
<5\end{array}$ \\
\hline Catechol 2,3-dioxygenase & Catechol & $<1$ & $<1$ & 370 & $<1$ \\
\hline $\begin{array}{l}\text { 2-Hydroxymuconic semialdehyde hydrolase } \\
\text { (HMSH) }\end{array}$ & 2-Hydroxy-6-oxohepta-2,4-dienoate & $<10$ & $<10$ & 295 & $<10$ \\
\hline Catechol 1,2-dioxygenase & $\begin{array}{l}\text { Catechol } \\
\text { 3-Chlorocatechol }\end{array}$ & $\begin{array}{l}490 \\
300\end{array}$ & $\begin{array}{r}200 \\
80\end{array}$ & $\begin{array}{l}80 \\
40\end{array}$ & $\begin{array}{r}6 \\
10\end{array}$ \\
\hline Muconate cycloisomerase & $\begin{array}{l}\text { cis,cis-Muconate } \\
\text { 2-Chloro-cis,cis-muconate } \\
\text { 3-Chloro-cis,cis-muconate } \\
\text { 2,4-Dichloro-cis,cis-muconate }\end{array}$ & $\begin{array}{r}8 \\
15 \\
370 \\
390\end{array}$ & $\begin{array}{l}<5 \\
<5 \\
75 \\
80\end{array}$ & $\begin{array}{r}<5 \\
<5 \\
65 \\
70\end{array}$ & $\begin{array}{l}<5 \\
<5 \\
<5 \\
<5\end{array}$ \\
\hline $\begin{array}{l}\text { 4-Carboxymethylbut-3-en-4-olide } \\
\text { hydrolase }\end{array}$ & 4-Carboxymethylbut-3-en-4-olide & 70 & 50 & 90 & 30 \\
\hline $\begin{array}{l}\text { 4-Carboxymethylenebut-2-en-4-olide } \\
\text { hydrolase }\end{array}$ & $\begin{array}{l}\text { trans-4-Carboxymethylenebut-2-en- } \\
\text { 4-olide }\end{array}$ & 2570 & 670 & 360 & 55 \\
\hline Maleylacetate reductase & Maleylacetate & 600 & 500 & 310 & 15 \\
\hline
\end{tabular}

a Cells were harvested during exponential growth phase. Enzyme activitiesof 2,4-D monooxygenase were determined with whole cells. Decrease of substrate concentration was followed by high pressure liquid chromatography. Phenol hydroxylation activities were also determined with whole cells. The specific oxygen uptake with phenols was divided by two, to get comparable activities. All other activities were determined by photometric tests using cell extracts

b 3,5-Dichlorocatechol was cleaved by partially purified catechol 1,2-dioxygenase of the type II and the accumulating product was used as assay substrate as described in the Materials and methods section. This product is not yet clearly identified as 2,4-dichloro-cis,cis-muconate

on 2,4-D, MCPA and 2MPA were compared. While 2MPAgrown cells had high activities of enzymes of a meta-cleavage pathway (Table 3), this pathway was not induced in 2,4-Dor MCPA-grown cells. Ortho-cleavage activity with catechol as well as with 3-chlorocatechol was found in all three cell extracts.

An elution profile from a DEAE-cellulose column of a cell extract prepared from 2,4-D-grown cells showed two separate peaks of catechol 1,2-dioxygenase (C120) activity. The fractions of the first peak, eluted at $0.22 \mathrm{M} \mathrm{NaCl}$, exhibited high activity against catechol and 3-chlorocatechol whereas fractions of the second peak, eluted at $0.23 \mathrm{M} \mathrm{NaCl}$, exhibited high activity against catechol only. Activities were also determined in pools of fractions from the flanks of the peaks to avoid contaminations by the respective isoenzymes. By measurements of the activity against catechol, both pools showed different stabilities under diverse storage temperatures (data not shown). Since the first pool showed constant relative activites against catechol/3-chlorocatechol/3,5dichlorocatechol under different storage conditions, it can be designated as a pure preparation of a C120 Type II (Dorn and Knackmuss 1978a). The second pool, preparation of a C120 type I enzyme showed impurities of its isoenzyme. The amount of impurity due to $\mathrm{C} 120 \mathrm{II}$ after storage for 6 days 
Table 4. Apparent $K_{\mathrm{m}}$ values and apparent $V_{\max }$ values of substituted catechols for two catechol 1,2-dioxygenases from Alcaligenes eutrophus JMP 134 grown on 2,4-D

\begin{tabular}{|c|c|c|c|c|}
\hline \multirow[t]{2}{*}{ Substrate } & \multicolumn{2}{|c|}{$\begin{array}{l}\text { Catechol } \\
\text { 1,2-dioxygenase I }\end{array}$} & \multicolumn{2}{|c|}{$\begin{array}{l}\text { Catechol } \\
\text { 1,2-dioxygenase II }\end{array}$} \\
\hline & $\begin{array}{l}V_{\max } \\
(\%)\end{array}$ & $\begin{array}{l}V_{\max } \\
(\mu \mathrm{M})\end{array}$ & $\begin{array}{l}V_{\max } \\
(\%)\end{array}$ & $\begin{array}{l}K_{\mathrm{m}} \\
(\mu \mathrm{M})\end{array}$ \\
\hline Catechol & 100 & 5.6 & 100 & 19.2 \\
\hline 3-Chlorocatechol & 2 & $\mathrm{ND}^{\mathrm{b}}$ & 124 & 2.0 \\
\hline 4-Chlorocatechol & 14 & ND & 122 & 0.5 \\
\hline 3,5-Dichlorocatechol & 1 & ND & 181 & 0.8 \\
\hline 3-Methylcatechol & 41 & 2.9 & 167 & 36.0 \\
\hline $\begin{array}{l}\text { 5-Chloro-3- } \\
\text { methylcatechol }\end{array}$ & 38 & ND & 376 & ND \\
\hline
\end{tabular}

a The kinetic constants were determined by use of double reciprocal plots $[1 /(\mathrm{S})$ against $1 / \mathrm{v}]$. All solutions were satured with air at $25^{\circ} \mathrm{C}$. Maximum velocities are given as percentages with respect to the reaction with catechol $(=100 \%)$

${ }^{\circ} \mathrm{ND}=$ not determined

at $-16^{\circ} \mathrm{C}$ was estimated to be less than $0.5 \%$. Apparent $K_{\mathrm{m}}$ values and maximum ring cleavage velocities $\left(V_{\max }\right)$ of catechols for the two catechol 1,2-dioxygenases are summarized in Table 4 . The ratio of maximum velocities of 1,2-dioxygenation of 3-chlorocatechol/catechol by C120 II was 1.24. A lower ratio points to additional induction of C120 I as can be seen in cell extracts of 2,4-D, MCPA- and 2MPA-grown cells (ratios of $0.61,0.40$ and 0.5 , respectively). About $50 \%, 35 \%$ and $40 \%$ respectively of the activities found against catechol were due to induction of C120 II.

\section{Degradation of muconates}

Schmidt and Knackmuss (1980) observed two muconate cycloisomerases in the 3-chlorobenzoate degrading organism Pseudomonas sp. B13. Isoenzyme I showed high activity only against muconate while isoenzyme II was active against both muconate and 2-chloromuconate. In contrast, cell extracts of 2,4-D-, MCPA- and 2MPA-grown cells of Alcaligenes eutrophus JMP 134 exhibited only very low activity against muconate and 2-chloromuconate. High activity, however, was found against 3-chloromuconate and against the ring-cleavage product of 3,5-dichlorocatechol, indicating a muconate cycloisomerase different from those of Psetdomonas sp. B 13. A muconate cycloisomerase of type I (Schmidt and Knackmuss 1980) with high activity against muconate is synthesized by Alcaligenes eutrophus JMP 134 when grown on phenol (data not shown).

Chlorosubstituted muconates were converted by Pseudomonas sp. B13 to chlorosubstituted 4-carboxymethylbut-2-en-4-olides, spontaneous elimination of chloride leading to formation of 4-carboxymethylenebut-2-en-4olide which is further converted to maleylacetate by a 4 carboxymethylenebut-2-en-4-olide hydrolase (Schmidt and Knackmuss 1980). Due to unavailability of chlorosubstituted 4-carboxymethylenebut-2-en-4-olide, the corresponding product of 2,4-dichloromuconate cycloisomerisation, trans-4-carboxymethylenebut-2-en-4-olide was used as test substrate. As shown in Table 4, activites for this substrate and for maleylacete were induced in 2,4-D-, MCPA- and also 2MPA-grown cells. Only low activities of

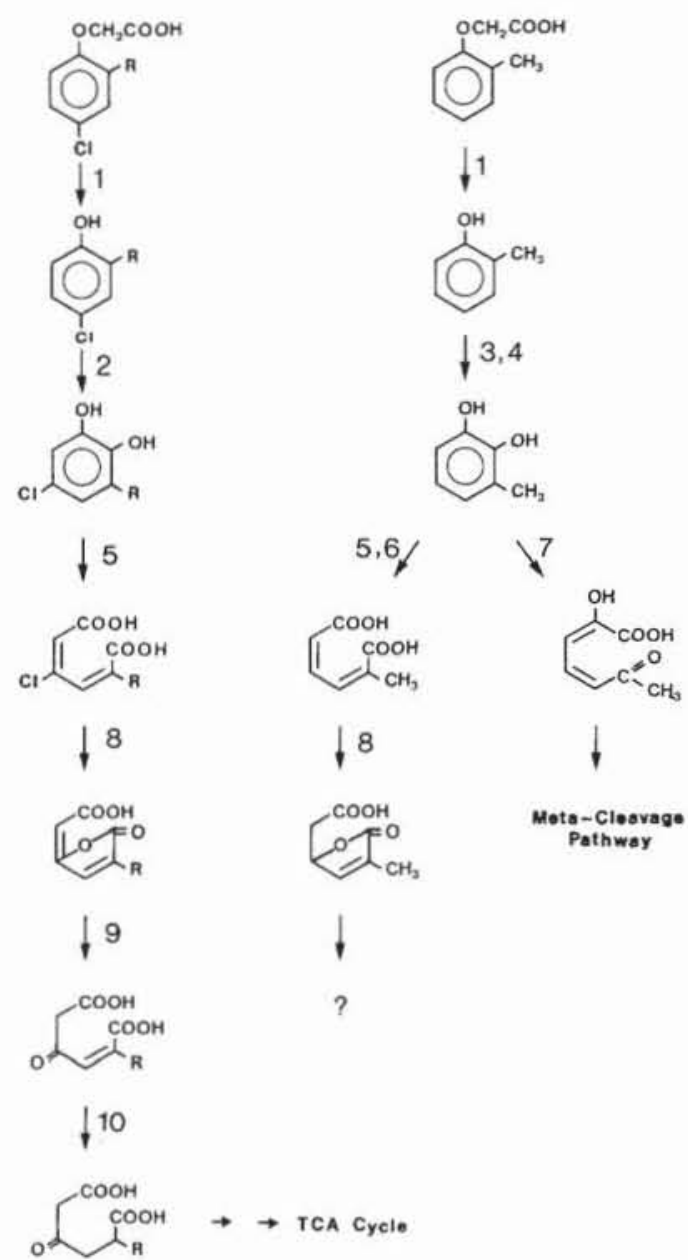

Fig. 1. Proposed pathways for the degradation of 2,4-dichloro$(\mathrm{R}=\mathrm{Cl})$, 4-chloro-2-methyl- $\left(\mathrm{R}=\mathrm{CH}_{3}\right)$ and 2-methylphenoxyacetic acid in Alcaligenes eutrophus JMP 134. The enzymes are follows: 1 2,4-D monooxygenase; 2 chlorophenol hydroxylase; 3, 4 phenol hydroxylase with different ratios of activities against phenol and methylphenols; 5 catechol 1,2-dioxygenase II; 6 catechol 1,2dioxygenase I; 7 catechol 2,3-dioxygenase; 8 specialized cis,cismuconate cycloisomerase; 9 4-carboxymethylenebut-2-en-4-olide hydrolase; 10 maleylacetate reductase

4-carboxymethylbut-3-en-4-olide hydrolase, an enzyme of the 3-oxoadipate-pathway, were induced in these cells.

\section{Discussion}

The present results demonstrate, that 2-methylphenoxyacetic acid (2MPA) is also a growth substrate for the 2,4 dichlorophenoxyacetic acid (2,4-D) and 4-chloro-2methylphenoxyacetic acid (MCPA) degrading Alcaligenes eutrophus JMP 134. The first catabolic step, cleavage of the ether bond to produce the respective phenols (Fig. 1), is apparently mediated by a single enzyme, probable a monooxygenase as described by Tiedje and Alexander (1969) and Gamar and Gaunt (1971). An initial ring hydroxylation or reductive elimination of chloride can be excluded. The 2,4D monooxygenase of strain JMP 134 has a wide substrate specifity, phenoxyacetic acid (PA) and 2MPA as well as 2,4$\mathrm{D}$ and MCPA being converted at high rates.

Clearly different enzymes acting on phenols (Table 2) were synthesized by strain JMP 134 during growth with 
different phenoxyacetic acids. 2,4-D grown cells from the early stationary growth phase exhibited high activity against 2,4-dichloro- and 4-chloro-2-methylphenol but not against phenol and 2- and 4-methylphenol. This indicates induction of the pJP4-encoded chlorophenol hydroxylase which had been purified by Liu and Chapman (1984). During exponential growth, additional activities against phenol, 2and 4-methylphenol were induced, in 2,4-D- and MCPAgrown cells in a ratio of $4: 1: 1$, in 2MPA-grown cells in a ratio of approximately $1: 1: 1$. These results indicate that, in addition to the described chlorophenol hydroxylase, two further phenol hydroxylating enzymes can be induced by JMP 134.

It is probable that the three phenol hydroxylases which can be synthesized by JMP 134, differ only in substrate specifity and that in each case the corresponding catechols are the products (Fig. 1). This has been shown for the chlorophenol hydroxylase by Liu and Chapman (1984). A second phenol hydroxylating activity, found in 2,4-D- and MCPA-grown cells (Table 2) showed high activity against phenol and is therefore assumed to be a ring-hydroxylating activity. Also a side chain attack by the third phenol hydroxylase of JMP 134, which exhibits high activity against 2methylphenol seems unlikely. Hydroxylases attacking the side chain of methylphenols which have been described, either attack methylgroups in meta-position to the hydroxylgroup (Hopper and Chapman 1971; Hopper and Taylor 1975; Keat and Hopper 1978) or specifically attacks the para-methylgroup of 4-methylsubstituted phenols (Keat and Hopper 1978; McIntire et al. 1985).

Three different enzymes acting upon catechols are inducible in JMP 134, two catechol 1,2-dioxygenases and one catechol 2,3-dioxygenase (Tables 3 and 4). Only orthocleavage activites were found in 2,4-D- and MCPA-grown cells of A. eutrophus JMP 134 (Fig. 1). This shows a strict regulation which prevents a misrouting of the chlorocatechols by induction of the meta-cleavage pathway, which for different reasons has been described to be unproductive for the degradation of chlorosubstituted catechols (Horvath 1970; Klecka and Gibson 1981; Surovtseva and Volnova 1981; Kaminski et al. 1983; Bartels et al. 1984). A similar strict regulation has been described only by Kilpi et al. (1983). In contrast, Reineke et al. (1982) showed that the loss of expression of $\mathrm{C} 230$ is obligatory for growth of Pseudomonas WR 211 on 4-chlorobenzoate. In this strain, 4-chlorobenzoate is totally channeled into the unproductive meta-pathway. A mutation in the structural gene of C230 prevents this misrouting in the derivative strain WR 216 (Jeenes et al. 1982). Latorre et al. (1984) and Rubio et al. (1986) showed a similar incompatibility of ortho- and metacleavage pathway in the same species.

2MPA-grown cells showed induction of both ortho- and meta-cleavage enzymes (Fig. 1). The degradation of this substrate via 3-methylcatechol and the well known metacleavage (Sala-Trepat et al. 1972; Murray et al. 1972; Dagley 1978) was not further investigated. It is currently studied, what proportion of 3-methylcatechol produced from 2MPA is channeled into the ortho-cleavage pathway and whether like 4-methylcatechol (Pieper et al. 1985), it can productively be metabolized via this route.

Two catechol 1,2-dioxygenases were induced in 2,4-D-, MCPA- and 2MPA-grown cells of JMP 134. Whereas isoenzyme II exhibited high activity against catechol and also chlorosubstituted catechols (Table 4), isoenzyme I exhibited high activity against catechol only, indicating a type of catechol 1,2-dioxygenase known from the classical 3oxoadipate pathway. A similar situation of induction of two catechol 1,2-dioxygenases after growth of bacterial strains on chloroaromatics has been described by Dorn and Knackmuss (1978a) and Reineke and Knackmuss (1980), but also the induction of only one catechol 1,2-dioxygenase with broad substrate specifity has been reported (Reineke and Knackmuss 1984). Due to the fact that chlorophenol hydroxylase of strain JMP 134, as shown by Liu and Chapman (1984), was highly specific against chlorophenols and exhibited no activity against unsubstituted phenol, we investigated if further enzymes, highly specific for chlorosubstituted substrates, were synthesized by strain JMP 134. Purification of catechol 1,2-dioxygenase active against chlorocatechols has already been carried out with bacterial species isolated on monochloroaromatics such as 3-chlorobenzoate (Reineke and Knackmuss 1980) and chlorobenzene (Reineke and Knackmuss 1984). The enzyme of Alcaligenes eutrophus JMP 134, however, was found to be specialized to 3,5-dichlorocatechol as substrate, which is converted faster than the monochlorosubstituted compounds. Also Kilpi et al. (1983) observed a significantly higher activity against 3,5-dichlorocatechol than against 3chlorocatechol in cell extracts of a pseudomonad isolated on 2,4-D.

Investigations on muconate cycloisomerizing enzymes in chloroaromatic-degrading bacterial species have been reported by Schmidt et al. (1980) and Hartmann et al. (1979). Using purified enzymes, Schmidt et al. (1980) showed that the 3-chlorobenzoate degrading Pseudomonas sp. B13 induces a muconate cycloisomerase type I with high activity only against muconate when grown on benzoate, while a muconate cycloisomerase type II with high activity against muconate and also against 2- and 3-chloromuconate is formed when grown on 3-chlorobenzoate. Independent of the substitution of the benzoates used as growth substrates by Hartmann et al. (1979), the authors found a considerably higher activity against 2-chloromuconate than against muconate. Since the authors investigated muconate cycloisomerizing activities only in cell extracts, it is not known if these activities are due to induction of only one cycloisomerase.

The muconate cycloisomerase induced by 2,4-D-grown cells of Alcaligenes eutrophus JMP 134 is highly specific. 2Chloromuconate and muconate were converted only at low rates, whereas high activities were found against 3chloromuconate and against the ring-cleavage product of 3,5-dichlorocatechol.

Products of cycloisomerisation of 2-chloromuconate and 3-chloromuconate by Pseudomonas sp. B13 have been identified by Schmidt and Knackmuss (1980) as trans- and cis-4-carboxymethylenebut-2-en-4-olide, respectively. Chloro-substituted 4-carboxymethylbut-2-en-4-olides, which spontaneously eliminate chloride, were assumed to be the reaction products. Both cis- and trans-4-carboxymethylenebut-2-en-4-olide were converted to maleylacetate by the action of 4-carboxymethylenebut-2-en-4-olide hydrolase (dienelactone hydrolase) (Schmidt and Knackmuss 1980). The fate of 2,4-dichloro- and 4-chloro-2-methylmuconate has not been as thoroughly examined. Bollag et al. (1968b), Tiedje et al. (1969), Evans et al. (1971b) and Sharpee et 
al. (1973) reported 2-chloro-4-carboxymethylenebut-2-en-4olide to be a metabolite in the degradation of 2,4-D. Gaunt and Evans (1971b) reported 2-methyl-4-carboxymethylenebut-2-en-4-olide as a metabolite in the degradation of MCPA. High activities against 4-carboxymethylenebut-2en-4-olide in 2,4-D- and 4-carboxymethylenebut-3-en-4 olide supports the assumption of the degradation of 2,4-D and MCPA via dienelactones as metabolites (Fig. 1).

Alcaligenes eutrophus JMP 134 is an unusual bacterium in that it harbours several sets of enzymes catabolizing differently substituted phenols and catechols. These are properly regulated in order to avoid misrouting of chlorocatechols into the unproductive meta-cleavage pathway. The second outstanding feature of this organism is its capability to assimilate at least 4-methylcatechol via an ortho-cleavage pathway (Pieper et al. 1985). Since the organism also harbours an efficient meta-cleavage pathway, both catechol 1,2- and catechol 2,3-activities become induced if confronted to mixtures of chloro- and methylaromatics (Pieper 1986). Because this may become a serious problem in industrial sewage treatment systems, simultaneous metabolism of methyl- and chloroaromatics is currently investigated.

Acknowledgements. This work has been partly supported by a grant from the Bundesministerium für Forschung und Technologie. We thank Prof. Dr. R. C. Bayly for critical reading of the manuscript.

\section{References}

Bartels I, Knackmuss HJ, Reineke W (1984) Suicide inactivation of catechol 2,3-dioxygenase from Pseudomonas putida $\mathrm{mt}-2$ by 3halocatechols. Appl Environ Microbiol 47:500-505

Beadle CA, Smith ARW (1982) The purification and properties of 2,4-dichlorophenol hydroxylase from a strain of Acinetobacter species. Eur J Biochem 123:323-332

Bollag JM, Helling CS, Alexander M (1968a) 2,4-D metabolism: Enzymatic hydroxylation of chlorinated phenols. J Agr Food Chem 16:826-828

Bollag J, Briggs GG, Dawson JE, Alexander M (1968b) 2,4-D metabolism: Enzymatic degradation of chlorocatechols. J Agr Food Chem 16:829-833

Bradford MM (1976) A rapid and sensitive method for the quantitation of protein utilizing the principle of protein-dye binding. Anal Biochem 72:248-254

Dagley S (1978) Pathways for the utilization of organic growth substrates. In: Gunsalus LC (ed) The bacteria, vol VI, Bacterial diversity. Academic Press, New York, pp 305-388

Don RH, Pemberton JM (1981) Properties of six pesticide degradation plasmids isolated from Alcaligenes paradoxus and Alcaligenes eutrophus. J Bacteriol 145:681-686

Don RH, Weightman AJ, Knackmuss HJ, Timmis KN (1985) Transposon mutagenesis and cloning analysis of the pathways for degradation of 2,4-dichlorophenoxyacetic acid and 3chlorobenzoate in Alcaligenes eutrophus JMP 134 (pJP4). J Bacteriol 161:85-96

Dorn E, Knackmuss HJ (1978a) Chemical structure and biodegradability of halogenated aromatic compounds: two catechol 1,2-dioxygenases from a 3-chlorobenzoate grown Pseudomonad. Biochem J 174:73-84

Dorn E, Knackmuss HJ (1978b) Chemical structure and biodegradability of halogenated aromatic compounds: substituent effects on 1,2-dioxygenation of catechol. Biochem J 174:8594

Dorn E, Hellwig M, Reineke W, Knackmuss HJ (1974) Isolation and characterization of a 3-chlorobenzoate degrading Pseudomonad. Arch Microbiol 99:61-70

Evans WC, Smith BSW, Moss P, Fernley HN (1971 a) Bacterial metabolism of 4-chlorophenoxyacetate. Biochem J 122: $509-517$
Evans WC, Smith BSW, Fernley HN, Davies JI (1971 b) Bacterial metabolism of 2,4-dichlorophenoxyacetate. Biochem J 122: $543-552$

Friedrich B, Meyer M, Schlegel HG (1983) Transfer and expression of the herbicide-degrading plasmid pJP4 in aerobic autotrophic bacteria. Arch Microbiol 143:92-97

Gaal AB, Neujahr HY (1980) Maleylacetate reductase from Trichosporum cutaneum. Biochem J 185:783-786

Gamar Y, Gaunt JK (1971) Bacterial metabolism of 4-chloro-2methylphenoxyacetate (MCPA): formation of glyoxylate by side-chain cleavage. Biochem J 122:527-531

Gaunt JK, Evans WC (1971a) Metabolism of 4-chloro-2methylphenoxyacetate by a soil Pseudomonad: preliminary evidence for the metabolic pathway. Biochem J 122:519-526

Gaunt JK, Evans WC (1971b) Metabolism of 4-chloro-2methylphenoxyacetate by a soil Pseudomonad: ring fission, lactonizing and delactonizing enzymes. Biochem J 122:533542

Hartmann J, Reineke W, Knackmuss HJ (1979) Metabolism of 3chloro-, 4-chloro- and 3,5-dichlorobenzoate by a Pseudomonad. Appl Environ Microbiol 37:421 - 428

Hopper DJ, Chapman PJ (1971) Gentisic acid and its 3- and 4methylsubstituted analogues as intermediates in the bacterial degradation of m-cresol, 3,5-xylenol and 2,5-xylenol. Biochem J 122:19-28

Hopper DJ, Taylor DG (1975) Pathways for the degradation of mcresol and p-cresol in Pseudomonas putida. J Bacteriol 122:16

Horvath RS (1970) Co-metabolism of methyl- and chloro-substituted catechols by an Achromobacter sp. possessing a new meta-cleaving oxygenase. Biochem J 119:871 -876

Jeenes DJ, Reineke W, Knackmuss HJ, Williams PA (1982) TOL plasmid pWWO in constructed halobenzoate-degrading Pseudomonas strains: enzyme regulation and DNA structure. J Bacteriol 150:180-187

Kaminski U, Janke D, Prauser H, Fritsche W (1983) Degradation of aniline and monochloroanilines by Rhodococcus sp. An 117 and a Pseudomonad: a comparative study. Z Allg Microbiol $22: 235-246$

Keat MJ, Hopper DJ (1978) p-Cresol and 3,5-xylenol methylhydroxylases in Pseudomonas putida N.C.I.B. 9869. Biochem J $175: 649-658$

Kilpi S, Backström V, Korhola M (1983) Degradation of catechol, methylcatechols and chlorocatechols by Pseudomonas sp. HV3. FEMS Microbiol Lett 18:1-5

Klecka GM, Gibson DT (1981) Inhibition of catechol 2,3dioxygenase from Pseudomonas putida by 3-chlorocatechol. Appl Environ Microbiol 41:1159-1165

Latorre J, Reineke W, Knackmuss HJ (1984) Microbial metabolism of chloroanilines: enhanced evolution by natural genetic exchange. Arch Microbiol 140:159-165

Lineweaver H, Burk D (1934) The determination of enzyme dissociation constants. J Am Chem Soc 56:658-666

Liu T, Chapman PJ (1984) Purification and properties of a plasmidencoded 2,4-dichlorophenol hydroxylase. FEBS Lett 173: $314-318$

Loos MA, Roberts RN, Alexander M (1967) Phenols as in termediates in the decomposition of phenoxyacetates by an Arthrobacter sp. Can J Microbiol 13:679-690

McIntire W, Hopper DJ, Singer TP (1985) p-Cresol methylhydroxylases: assay and general properties. Biochem J $228: 325-335$

Miller DJ (1981) Toluate metabolism in nocardioform Actinomycetes: utilization of the enzymes of the 3-oxoadipate pathway for the degradation of methyl-substituted analogues. In: Schaal KP, Pulverer G (eds) Actinomycetes, Zbl Bakt Suppl 11. Fischer, Stuttgart New York, pp 355-361

Murray K, Duggleby CJ, Sala-Trepat JM, Williams PA (1972) The metabolism of benzoate and methylbenzoates via the metacleavage pathway by Pseudomonas arvilla $\mathrm{mt}-2$. Eur $\mathrm{J}$ Biochem $28: 301-310$ 
Nakazawa T, Yokota T (1973) Benzoate metabolism in Pseudomonas putida (arvilla) mt-2: demonstration of two benzoate pathways. J Bacteriol 115:262-267

Nozaki M (1970) Metapyrocatechase (Pseudomonas). In: Tabor H, Tabor CW (eds) Methods in enzymology, vol 17A. Academic Press, New York, pp 522-525

Ornston LN (1966) The conversion of catechol and protocatechuate to $\beta$-ketoadipate by Pseudomonas putida. II. Enzymes of the protocatechuate pathway. J Biol Chem 241:3787-3794

Pieper DH (1986) Metabolismus von substituierten Phenoxyacetaten, Phenolen and Benzoaten durch Alcaligenes eutrophus JMP 134 and Derivate. Dissertation, Universität Wuppertal

Pieper DH, Engesser KH, Don RH, Timmis KN, Knackmuss HJ (1985) Modified ortho-cleavage pathway in Alcaligenes eutrophus JMP 134 for the degradation of 4-methylcatechol. FEMS Microbiol Lett 29:63-67

Powlowski JB, Dagley S (1985) $\beta$-Ketoadipate pathway in Trichosporum cutaneum modified for methyl-substituted metabolites. J Bacteriol 163:1126-1135

Reineke W, Knackmuss HJ (1980) Hybrid pathway for chlorobenzoate metabolism in Pseudomonas sp. B 13 derivatives. J Bacteriol 142:467-473

Reineke W, Knackmuss HJ (1984) Microbial metabolism of haloaromatics: isolation and properties of a chlorobenzenedegrading bacterium. Appl Environ Microbiol 47:395-402

Reineke W, Jeenes DJ, Williams PJ, Knackmuss HJ (1982) TOL plasmid pWWO in constructed halobenzoate-degrading Pseudomonas strains: prevention of meta pathway. J Bacteriol 150:195-201

Rubio MA, Engesser KH, Knackmuss HJ (1986) Microbial metabolism of chlorosalicylates: accelerated evolution by natural genetic exchange. Arch Microbiol 145:116-122

Sala-Trepat JM, Murray K, Williams PA (1972) The metabolic divergence in the meta-cleavage of catechols by Pseudomonas putida NCIB 10015: physiological significance and evolutionary implications. Eur J Biochem 28:347-356

Schmidt E, Knackmuss HJ (1980) Chemical structure and biodegradability of halogenated aromatic compounds: conversion of chlorinated muconic acids into maleoylacetic acid. Biochem J 192:339-347

Schmidt E, Remberg G, Knackmuss HJ (1980) Chemical structure and biodegradability of halogenated aromatic compounds: halogenated muconic acids as intermediates. Biochem J 192:331-337

Schmidt K, Liaaen Jensen S, Schlegel HG (1963) Die Carotinoide der Thiorhodaceae. I. Okenon als Hauptcarotinoid von Chromatium okenii Perty. Arch Mikrobiol 46:117-126

Schreiber A, Hellwig M, Dorn E, Reineke W, Knackmuss HJ (1980) Critical reactions in fluorobenzoic acid degradation by Pseudomonas sp. B 13. Appl Environ Microbiol 39:58-67

Sharpee KW, Duxbury JM, Alexander M (1973) 2,4-Dichlorophenoxyacetate metabolism by Arthrobacter sp.: accumulation of a chlorobutenolide. Appl Microbiol 26:445-447

Streber WR, Timmis KN, Zenk MH (1987) Analysis, cloning and bigh-level expression of 2,4-dichlorophenoxyaceteate monooxygenase gene tfdA of Alcaligenes eutrophus JMP 134. J Bacteriol 169:2950 - 2955

Surovtseva EG, Volnova AI (1981) 4-Chlorocatechol, and inhibitor of pyrocatechol 2,3-dioxygenase in Alcaligenes faecalis. Microbiologiya 50:386-388

Tiedje JM, Alexander M (1969) Enzymatic cleavage of the ether bond of 2,4-dichlorophenoxyacetate. J Agr Food Chem 17:1080-1084

Tiedje JM, Duxbury JM, Alexander M, Dawson JE (1969) 2,4D metabolism: pathway of degradation of chlorocatechols by Arthrobacter sp. J Agr Food Chem 17:1021-1026

Williams PA, Murray K (1974) Metabolism of benzoate and the methylbenzoates by Pseudomonas putida (arvilla) mt-2: evidence for the existence of a TOL plasmid. J Bacteriol 120:416-423

Winnacker K, Küchler L (1972) Chemische Technoloogie, Band 4, Organische Technologie. Hanser, München

Received December 2, 1987/Accepted February 3, 1988 